Dr BLAŽ TORKAR, naučni saradnik

Center vojaških šol Slovenske vojske/Vojaški muzej

Maribor, Engelsova 15, Republika Slovenija

blaž.torkar@gmail.com

Dr BOJAN B. DIMITRIJEVIĆ, naučni savetnik

Institut za savremenu istoriju

Beograd, Trg Nikole Pašića 11, Republika Srbija

bojands1@gmail.com

originalan naučni rad

UDK: 355.426(497.4)"1991"

primljeno: 29. avgust 2017.

prihvaćeno: 15. novembar 2017. DOI: 10.29362/IST20VEKA.2018.1.TOR.179-198

\title{
SUKOB JNA I TERITORIJALNE ODBRANE SLOVENIJE NA SEVERNOJ PRIMORSKOJ 1991.
}

APSTRAKT: U članku se osvetljava jedna važna ratna epizoda u Sloveniji 1991. i ukazuje se na određena problemska pitanja u interpretacijama tog događaja. Poseban problem u izučavanju sukoba u Sloveniji leta 1991, kao zaokružene celine ili samo dela ratova u kojima će se SFR Jugoslavija raspasti, čini skoro potpuna nedostupnost arhivske građe Jugoslovenske narodne armije (JNA). I na slovenačkoj strani takođe postoje problemi oko originalne arhivske građe. Za pojedine događaje nisu sačuvani ili uopšte ne postoje pisani tragovi. U Sloveniji, proučavanje ovog sukoba je počelo neposredno posle njegovog završetka. Tokom vremena se pojavio veći broj memoarskih, publicističkih, a kasnije i naučnih radova o ovoj temi. Takođe, i izvesna količina sačuvanih video-snimaka, kasnijih TV emisija, dokumentarnih filmova ili snimljenih svedočenja aktera rata. U mnogima od njih je istaknuta uloga slovenačke strane a relativno malo ili negativno opisana uloga JNA, što je i razumljivo iz ugla pobednika. U Srbiji, detaljnijeg proučavanja rata u Sloveniji nije bilo, najviše zbog nedostupnosti primarnih izvora. Članak je zasnovan na dostupnoj arhivskoj građi Teritorijalne odbrane Slovenije u Vojnom muzeju Slovenačke vojske, a delimično i JNA, na većem broju publicističkih, memoarskih radova i na nekoliko usmenih izvora.

KLJUČNE REČI: Jugoslavija, Slovenija, Primorska, Jugoslovenska narodna armija, Teritorijalna odbrana, rat

\section{Snage JNA na Severnoj Primorskoj}

Posle reorganizacije po planu Jedinstvo 2/3, koja je na prostoru Severne Primorske sprovedena na prelazu 1990. u 1991, snage JNA su u znatnoj meri smanjene. Ovo područje Slovenije bilo je u nadležnosti komande 5. vojne oblas- 
ti, odnosno njenog 14. korpusa sa sedištem u Ljubljani. Armija je na ovom prostoru imala 228. motorizovanu brigadu (mtbr) sa komandom u Postojni. ${ }^{1}$ Njene jedinice su bile raspoređene u garnizonima Pivka, Postojna i Vipava. Prevođenjem 253. motorizovane brigade, koja je bazirala u Ajdovščini i Vipavi, u R status krajem 1990, njene aktivne jedinice preuzela je 228. brigada (motorizovani, inžinjerski bataljon), garnizona ambulanta u Vipavi). ${ }^{2}$ Od jednog motorizovanog bataljona ranije 253. mtbr u Vipavi stvorene su dve čete za obuku graničara, u sastavu dva granična bataljona: u Sežani i Novoj Gorici. Preostale jedinice 253. brigade, čija se nadležnost sada svodila samo na garnizon Ajdovščina (i oklopni bataljon R u Vipavi), bile su u suštini sve deaktivirane - u statusu R. ${ }^{3}$ Njihovo formacijsko navođenje u pojedinim radovima kao aktivnih jedinica ne odgovara realnosti $u$ trenutku početka sukoba. Severnije, garnizon $u$ Tolminu bio je u nadležnosti 345. planinske brigade (plbr) sa komandom u Kranju, koja je do rata tu imala detaširan jedan (4.) planinski bataljon R. U Ajdovščini je postojala i komanda ratne 19. partizanske brigade koja je pripadala ratnoj formaciji 30. partizanske divizije, a njena sredstva i naoružanje su čuvani u skladištima (Črni vrh ob Idrijo). Na ovom prostoru bio je centar EI i PED Rijavci. Granicu prema Italiji obezbeđivali su granični bataljoni: 64. u Sežani, 63. u Ajševici kod Nove Gorice i, severnije, 62. u Tolminu. U sastavu tih bataljona bile su granične karaule, čete za obuku i interventni vodovi. ${ }^{4}$

Kako je proces osamostaljenja Slovenije tekao početkom 1991, tako je došlo do postepenog podizanja borbene gotovosti u jedinicama JNA na ovom području. Generacija vojnika koja je stigla na odsluženje decembra 1990, imala je u garnizonu Vipava skraćenu pešadijsku obuku od samo 2 meseca i 20 dana (u odnosu na raniju od 4 meseca), pre upućivanja na granicu. ${ }^{5}$ Slovenački izvori beleže da je 18. juna 1991. komandant 345. plbr iz Kranja obišao jedinicu u Tolminu i doneo nacrt za izvođenje obuke sa novim vojnicima. Ovo naređenje je predviđalo ubrzanu obuku, izvođenje svih predviđenih bojevih gađanja već u prvom mesecu obuke, težište u obuci na odbrani kasarni. U svim jedinicama JNA na Primorskoj tih dana starešine su informisane o situaciji u državi, stanju u JNA, a povećana je i kontrola nad starešinskim sastavom. ${ }^{6}$

\footnotetext{
${ }^{1}$ Ministarstvo odbrane Republike Srbije, Sektor za ljudske resurse, Uprava za organizaciju, Naredba SSNO državna tajna 432-2, 5. mart 1990; Isto, s. pov. 473-1, 21. februar 1991.

${ }^{2}$ Isto, Nar. SSNO s. pov. 473-1, 21. februar 1991. Inžinjerijski bataljon je ostao u Vipavi, ali je prema naređenju od 21. februara 1991. trebalo da pređe u Ajdovščinu, u kasarnu Pale.

${ }^{3}$ Isto, Nar. SSNO 432-21, 31. oktobar 1990; Isto, 432-12, 23. jul 1990, (dogradnja po planu Jedinstvo 2 i 3 ).

${ }^{4}$ Rekonstrukcija na bazi sećanja autora (B. D.) kao i: Andrej Lovšin, Skrita vojna, spopad varnostno-obveščevalnih služb 1990-1991 (Ljubljana: Alpe Avro, Mladinska knjiga, 2001), 44-50.

${ }^{5}$ Izjava Ilije Panova, facebook zatvorena grupa vp 1266 Vipava 65271 Ajdovščina, JNA.

${ }^{6}$ Vojaški muzej Slovenske vojske (VMSV), zbirka arhivalij (ZA), fond Obrambna vojna 1991 (OV 1991), tehnična enota 4, OVS/91/4-66/2000, OVS/91/4-56/2000, Poročilo o zbranih informacijah na dan 18. in 19. 6. 1991, 1-2; Vito Berginc, „Načrt „Jezero“““, v: Trdna mreža. osamosvajanje Slovenije v Zgornjem Posočju, ur. Roman Medved (Tolmin: Območno združenje veteranov vojne za Slovenijo Gornje Posočje, 2008), 95-96; Bogdan Beltram, „Priprave in izvajanje osamosvojitvene vojne na Severni Primorski - leta 1990/1990”, v: Njim vsem pripada
} 
Po naređenju Generalštaba Oružanih snaga SFRJ, u maju 1991. došlo je do podizanja mera borbene gotovosti. Komandant 5. vojne oblasti general Konrad Kolšek navodi da je jedan oklopni bataljon T-55 iz Skoplja razmešten u Pivku, a da je naređena (,naložena nam je“) dekonzervacija dva oklopna bataljona R kod 228. motorizovane brigade. $^{7} \mathrm{O}$ ovim pojačanjima nemamo nikakve potvrde. Ipak, određen broj aktivnih pripadnika oklopnih jedinica (starešina i vojnika) iz Niša prekomandovan je u maju 1991. za popunu 2. okb/228. mtbr u Pivci, koji je bio R klasifikacije i nije imao ljudstvo. ${ }^{8}$

\section{Teritorijalna odbrana Slovenije}

U SR Sloveniji, Teritorijalna odbrana (TO) razvijala se drugačije nego u ostalim republikama SFR Jugoslavije. Tako se u delu njenih aktivnih pripadnika, a još više u delu rezervnog sastava, ona vremenom počela smatrati slovenačkom vojskom. Posle višestranačkih izbora i demokratskih promena u Sloveniji 1990, većina pripadnika TO je podupirala demokratske promene u svojoj republici.

Snagama TO Slovenije komandovao je Republički štab TO. Njegovu strukturu činilo je sedam pokrajinskih štabova, koji su bili podeljeni na ukupno 26 područnih-opštinskih štabova. Ova teritorijalna struktura razvijala je brojne jedinice TO u svom sastavu. Područje Severne Primorske obuhvatalo je početkom leta 1991. opštine Ajdovščina, Nova Gorica, Idrija i Tolmin. Do leta 1990, svaka opština imala je svoj štab TO, čija je delatnost bila tesno povezana sa jedinicama JNA i ogledala se u zajedničkim aktivnostima i vežbama. Ipak, sa procesom demokratizacije slovenačkog društva postepeno se menjalo vođstvo, pa i uloga ove strukture.

Delovanje TO na području Severne Primorske bilo je u nadležnosti 6 . pokrajinskog štaba Teritorijalne odbrane (6. PŠTO). Ovaj štab je do oktobra 1990. imao sedište u kasarni u Ajševici - gde je bilo i sedište 63. graničnog bataljona JNA. Do 4. oktobra štab su sačinjavali aktivne starešine JNA i rezervni oficiri TO. Potom je, u tajnosti od JNA, štab predislociran u zgradu uprave za unutrašnje poslove u Novoj Gorici zaključno sa 26. oktobrom $1990{ }^{10}$

slava: osamosvojitveno dogajanje Ajdovščina, Idrija, Nova Gorica, Tolmin, ur. Stanislav Bačar (Nova Gorica: Goriški muzej, 2009), 537-540.

${ }^{7}$ Konrad Kolšek, Prvi pucnji u SFRJ, sećanja na početak oružanih sukoba (Beograd: Dangraf, 2005), 127.

8 „Ti divni ljudi, hrabri mladi ratnici“, Narodna armija, 22. 12. 1991; Davor Marijan, Smrt oklopne brigade, (Zagreb-Sarajevo: Naklada Zoro, 2002), 158-159; Vaso Predojević, U procjepu, dnevničke zabilješke o razbijanju Partije, Armije, Države (Beograd: Dangraf, 1997), 90, 138-142; Janez Janša, Premiki, nastajanje in obramba slovenske države 1988-1992 (Ljubljana: MK, 1992), 125-138, 276 314; Janez J. Švajncer, Obranili domovino: teritorijalna obramba Republike Slovenije v vojni za svobodno in samostojno Slovenijo 1991 (Ljubljana: Viharnik, 1993), 16-17.

${ }^{9}$ Ističemo monografiju Vojaška obramba Slovenije1990-1991, urednik Tomaž Kladnik (Ljubljana: Defensor, 2011), u kojoj su slovenački istoričari dali pregled ratnih događanja po pokrajinama, dok za događaje u Severnoj Primorskoj poseban značaj ima zbornik sećanja aktera i dokumenata sa slovenačke strane Njim vsem pripada slava: osamosvojitveno dogajanje Ajdovščina, Idrija, Nova Gorica, Tolmin, ur. Stanislav Bačar (Nova Gorica: Goriški muzej, 2009).

${ }^{10}$ B. Beltram, op. cit., 535-553. 
Pogoršanje odnosa između JNA i TO Slovenije posebno je eskaliralo posle donošenja naredbe za preuzimanje oružja TO od strane JNA 15. maja 1990. Na prostoru Severne Primorske TO je imala veći deo svog naoružanja u skladištima JNA, sa izuzetkom nekih preduzeća. Slovenačka TO je tako ostala bez oružja i materijalno-tehničkih sredstava, a odnosi između JNA i TO Slovenije posle ove naredbe Generalštaba JNA su se zaoštrili. Slovenački odgovor se sastojao u stvaranju (ilegalne) Manevarske strukture narodne zaštite (MSNZ). Ova struktura je spajala sve elemente - ljudstvo TO, unutrašnjih poslova i milicije, a imala je i svoje naoružanje. Na području Severne Primorske MSNZ je započela delovanje 6. septembra 1990, kada je imenovan načelnik pokrajinske MSNZ Drago Vidrih. MSNZ je uključivala pažljivo odabrane predstavnike svih struktura, koji su do početka sukoba - rata za osamostaljenje, prikupili toliko oružja i vojne opreme da su jedinice TO u kritičnom času bile srazmerno dobro naoružane i opremljene. ${ }^{1}$

U periodu od decembra 1990, traje intenzivna reorganizacija i prilagođavanje snaga TO Slovenije novonastalim političkim okolnostima. Od početka 1991, u svim opštinskim štabovima radi se na osposobljavanju jedinica koje su bile namenjene za eventualnu intervenciju i odgovor na moguće „provokacije“, u suštini: od strane JNA. Tako se radi na osposobljavanju jedinica posebne namene, diverzantskih, izviđačkih, protivoklopnih ili jedinica veze. ${ }^{12} \mathrm{U}$ prvoj polovini 1991. godine uspostavljena je kontrola nad evidencijom vojnih obveznika, izvedena je komandno-štabna vežba Kobra 91 sa uvežbavanjem prebaziranja komandnog mesta i vežba angažovanih snaga veličine bataljona koji je izvršio pokret na većoj razdaljini, $14-15$. februara $1991 .^{13}$ U periodu $22-24$. marta 1991, izvedena je veća vežba TO Severnoprimorske i Dolenjske, kao i prištapskih jedinica Republičkog štaba TO pod nazivom Premik 91. Cilj vežbe je bio provera mobilizacije, taktičkog delovanja jedinica TO u napadnim delovanjima u pokretu i protivdiverzantska borba.

Reorganizacijom TO Slovenije, koja je bila izvedena od 1. juna 1991. na temelju republičkog Zakona o odbrani donetog 6. aprila 1991, od 62 opštinska štaba TO stvoreno je 26 područnih štabova. Na Severnoj Primorskoj od četiri opštinska (Ajdovščina, Nova Gorica, Tolmin, Idrija) formirana su dva područna (območna) štaba - 61. u Novoj Gorici i 63. obm ŠTO u Tolminu. Reorganizacija je izvedena brzo, pa je u praksi uočen određen broj organizacijskih i sadržajnih problema, između ostalog zato što su raniji štabovi nevoljno pristajali na potčinjavanje novoj organizacionoj strukturi, naročito na području 63. obm ŠTO Tolmin.

\footnotetext{
${ }^{11}$ Tomaž Kladnik, „Teritorialna obramba v obrambi suverenosti Republike Slovenije“, v: Vojaška obramba Slovenije 1990-1991, 7-17; „Koordinacijska podskupina 'Severna Primorska' v osamosvojitvenem času“", v: Njim vsem pripada slava, 22-26.

${ }^{12}$ VMSV, ZA, OV 1991, t. e. 12, Ukaz za usposabljanje ter obrambo Severnoprimorske pokrajine za leto 1991, januar 1991, 2.

${ }^{13}$ VMSV, ZA, OV 1991, t. e. 12, Ocena $\breve{S V V ~ „ K o b r a-91 ~ “, ~ 804-04 / 54, ~ 29 . ~ 4 . ~ 1991, ~ 1-9 . ~}$

${ }^{14}$ VMSV, ZA, OV 1991, t. e. 12, RS 6. PŠTO, Analiza VTV „Premik-91“, SZ-804-04/48, 11. 4. 1991, 1-3.
} 
Kako se ubrzavao proces osamostaljenja Slovenije, tako je rastao broj jedinica TO. Puna borbena gotovost dostignuta je 24. juna 1991, sa mobilizacijom većeg broja jedinica 6 . PŠTO na celom području pokrajine. U periodu borbenih dejstava, od 26. juna do 2. jula (ali i kasnije do 17. jula) 1991, sve poslove odbrane i bezbednosti vodi i usklađuje Koordinacijska podgrupa Severne Primorske sa sedištem u Upravi unutrašnjih poslova u Novoj Gorici. ${ }^{15}$ Njeno stvaranje je bilo nužno jer su dejstva izvodile snage TO i Milicije, a bila je potrebna koordinacija sa elementima lokalne samouprave. Podgrupa je davala odobrenja za najsloženije akcije, posebno one u kojima je korišćeno oružje. ${ }^{16}$

$\mathrm{Na}$ prostoru Vipavske doline i pravcu prema granici sa Italijom delovao je 61. obm ŠTO. Na dan proglašenja nezavisnosti ovaj štab je već aktiviranim jedinicama TO pridodao-aktivirao i dodatne snage. Deo jedinica je dislociran blizu komunikacija gde se očekivao prodor snaga JNA, dok se drugi deo koji se tek mobilisao i osposobljavao nalazio dalje od pravaca očekivanog prodora JNA. Na nove lokacije su izmešteni štabovi 6. PŠTO i 61. obm ŠTO, a formirana su nova skladišta naoružanja i opreme u saradnji sa lokalnim preduzećima i strukturom civilne zaštite. Takođe, jedinice TO su dobile zadatak da obezbeđuju sve vitalne objekte na širem području pokrajine, pored objekata društvenopolitičkih organizacija i lokalne samouprave, Uprave carina u Novoj Gorici, objekata PTT Nova Gorica i posebno RTV predajnika na Nanosu i Trstelju. Za očekivane prebegle vojnike iz redova JNA formirana je četa u Lokvama, a za zarobljenike koji su počeli da se prikupljaju od 28. juna i centar u osnovnoj školi u Solkanu. ${ }^{17}$

$\mathrm{U}$ toku borbenih dejstava aktivirane su dodatne jedinice 61. štaba 6 . PŠTO. ${ }^{18}$ Jedinice 6 . PŠTO na ovom području dostigle su početkom jula 1991. brojnost od 2.984 pripadnika. ${ }^{19}$ Pored većeg broja manjih „klasičnih“ jedinica TO, u sastavu 6. PŠTO delovala je i diverzantska grupa kojom je komandovao major Srečko Lisjak, pod nazivom Samostojna bojna skupina (SBS) ${ }^{20}{ }^{2} \mathrm{U}$ suštini, organizacijom TO Slovenije nepredviđena, ova jedinica odigraće presudnu ulogu u sukobu sa JNA na Primorskoj, a po efektima značajnu ulogu i u celom sukobu u Sloveniji.

${ }^{15}$ Činili su je načelnik uprave za unutrašnje poslove Stanislav Bačar, načelnik inspektorata milicije Aldo Turk, samostalni inspektor milicije Zvonimir Kelhar, komandant 6. PŠTO Bogdan Beltram i koordinator poslova u Ministarstvu za odbranu za Severnu Primorsku Drago Vidrih, kao komandant.

${ }^{16}$ VMSV, ZA, OV 1991, t. e. 12, Načrt varovanja objektov, 804-03/69, 24. 6. 1991, 1-2; VMSV, ZA, OV 1991, t. e. 3, Analiza bojnega dejstvovanja TO 6. PŠTO, 804-03/213, 17. 7. 1991, 1; „Koordinacijska podskupina 'Severna Primorska' v osamosvojitvenem času“, v: Njim vsem pripada slava, 24-25, 30-31.

${ }^{17}$ Rafael Mokorel, „Delovanje enot 61. Območnega štaba TO Nova Gorica v letu 1991”, v: Njim vsem pripada slava, 574-578.

${ }^{18}$ Rafael Mokorel, „Štabi in enote TO, ki so v osamosvojitveni vojni 1991 delovale na območju 61. Območnega štaba TO“, v: Njim vsem pripada slava, 579-580; Blaž Torkar, „Severnoprimorska pokrajina TO“, v: Vojaška obramba Slovenije 1990-1991, 377-419.

${ }^{19}$ VMSV, ZA, OV 1991, t. e. 12, Načrt varovanja objektov, 804-03/69, 24. 6. 1991, 1-2; VMSV, ZA, OV 1991, t. e. 3, Analiza bojnega dejstvovanja TO 6. PŠTO, 804-03/213, 17. 7. 1991, 1; „,Koordinacijska podskupina 'Severna Primorska' v osamosvojitvenem času“, v: Njim vsem pripada slava, 24-25.

${ }^{20}$ Pričevalci (Srečko Lisjak), rtvslo. si/pricevalci/oddaja/174412407. 


\section{„Dan prej“: pokret snaga JNA 26. juna 1991.}

Parlament Republike Slovenije (i Hrvatske, takođe) usvojio je 25. juna 1991. deklaraciju o suverenosti i nezavisnosti. ${ }^{21}$ Savezna vlada je te dokumente proglasile ništavnim i vojska je prvi put dobila odobrenje za borbena dejstva. Predsednik Saveznog izvršnog veća Ante Marković potpisao je Odluku o neposrednom obezbeđivanju izvršavanja saveznih propisa o prelaženju državne granice na teritoriji Republike Slovenije i Naredbu o zabrani uspostavljanja takozvanih graničnih prelaza unutar teritorije SFRJ. ${ }^{22}$ Savezni sekretarijati za narodnu odbranu i unutrašnje poslove ovlašćeni su za sprovođenje naredbe. Prema planu za preuzimanje kontrole nad graničnim prelazima u Republici Sloveniji, transportnim avionima je prevezen 461 pripadnik brigade Saveznog SUP-a i 270 carinika do aerodroma Cerklje, odakle je trebalo da se helikopterima rasporede po graničnim prelazima. ${ }^{23}$

General Kolšek piše: „Cilj akcije za granične prelaze od strane 5. VO, bio je jačim vojnim prisustvom omogućiti saveznim organima preuzimanje graničnih prelaza i preuzimanje carine. Izričito je naređeno da je potrebno izbeći oružani sukob, a oružje upotrebljavati samo u samoodbrani i u slučaju napada na jedinice. Zadatak JNA je bio: uspostaviti prvobitno stanje na državnoj granici u R. Sloveniji. Svojim prisustvom na graničnoj liniji i graničnim prelazima, uz angažovanje graničnih jedinica JNA, obezbediti izvršavanje saveznih propisa o prelaženju državne granice na teritoriji R. Slovenije. U tom cilju, ostvariti sadejstvo i pružiti neposredno pomoć organima Saveznog SUP-a i Savezne carine u prevoženju na granične prelaze i njihovom preuzimanju poslova kao i zaštite u radu, smeštaju i snabdevanju odgovarajućim potrebama“. ${ }^{24} \mathrm{~S}$ druge strane, komandant 6. PŠTO Bogdan Beltram je 26. juna 1991. naredio 61. i 63. obm ŠTO da zajedno sa organima unutrašnjih poslova obezbede međunarodne prelaze i da se zadaci izvrše bez upotrebe sile, a da će o eventualnoj upotrebi jedinica TO odlučiti Predsedništvo Republike Slovenije. ${ }^{25}$ Narednog dana komandant 6 . PŠTO je informisao svoje štabove da treba pričekati dalje zaoštravanje odnosa sa JNA i saveznim organima, kao i da se očekuje da će oni pokušati da uspostave kontrolu nad međunarodnim graničnim prelazima u Sloveniji. Teritorijalnoj odbrani je naređeno da aktivnost JNA mora sprečiti svim silama, pa i upotrebom oružja. ${ }^{26}$

Dvadeset šesti jun 1991. i pokreti snaga JNA izvedeni tog dana poznati su u slovenačkoj istoriografiji i publicistici kao „Dan prej“. ${ }^{27}$ Radi zauzimanja

${ }^{21}$ Kosta Nikolić i Vladimir Petrović, Rat u Sloveniji - Dokumenta Predsedništva SFRJ 2 (Beograd: ISI, 2012), 85-87.

22 „Odluka SIV-a, Zaključci Saveznog veća Skupštine SFRJ“, Narodna armija, 4. 7. 1991, 4; „Energično reagovanje SIV na odluke Hrvatske i Slovenije“, Borba, 27. 6. 1991, 1-2; isto, Politika, 27. 6. 1991, 1; J. Janša, op. cit., 157-159; K. Nikolić i V. Petrović, n. d., 88-91.

${ }^{23}$ V. Predojević, $n$. $d ., 98$.

${ }^{24} \mathrm{~K}$. Kolšek, $n$. $d$., 171.

${ }^{25}$ VMSV, ZA, OV 1991, t. e. 12, Z804-02/8, 26. 6. 1991.

${ }^{26}$ VMSV, ZA, OV 1991, t. e. 12, 27. 06. 1991 ob 15. uri, 1.

${ }^{27}$ Helena Race, „Dan Prej 26 junij 1991“ (diplomsko delo, Univerza u Ljubljani, Fakulteta za 
međunarodnih graničnih prelaza u Severnoj Primorskoj, u kasarni u Pivci, formirana je borbena grupa (1. tč /1. okb i 1. tč /2. okb) neposredno pred polazak na zadatak. Iako su opšte pripreme vršene duže vreme pred borbena dejstva, kasnije je ocenjeno da su neposredne pripreme za zadatak izvedene $u$,malo vremena" i da je to bilo presudno za dalji tok borbenih dejstava. Raspoloživo vreme do pokreta utrošeno je za izdavanje zapovesti za marš. „U neposrednim pripremama bilo je dosta propusta, jer nisu izvršene kompletne materijalne pripreme“ ${ }^{28}$ Komandu nad akcijom preuzimanja graničnih prelaza vodio je pukovnik Budimir Gavrić iz komande 14. korpusa u Ljubljani, koji je bio sa komandantom 63. graničnog bataljona majorom Miloradom Mijatovićem u Ajševici.

Koordinacijskoj podgrupi u Novoj Gorici iz Koordinacijske podgrupe $u$ Postojni javljeno je oko 11.05 časova o mogućnosti pokreta borbenih - oklopnih vozila iz Pivke u smeru ka Vipavskoj dolini. Pokret je ubrzo usledio. Borbena grupa 228. mtbr sastavljena od 20 tenkova (dva pokvarena tenka ostala su u Pivci), komandnog oklopnog transportera BTR-50, tenka za izvlačenje i tri motorna vozila krenula je u 11 časova iz Pivke prema Vipavi. ${ }^{29}$ „Predviđen broj tenkova i oklopnih transportera imao je dvojaku funkciju: zaštitu žive sile u toku izvršenja zadatka ovladavanja graničnim prelazima i demonstraciju sile pred javnošću i državno-političkim rukovodstvom Slovenije“. ${ }^{30}$

Ova kolona, koja se prikupila u Hruševlju, krenula je na severozapad, preko Bukovlja ka Vrhpolju i Vipavi. Skretanje sa glavnog puta bilo je prouzrokovano barikadama postavljenim na deonici Razdrto-Podnanos. Kolona se tri puta zaustavljala oko sela i u samom selu Vrhpolje, uglavnom zbog manjih barikada i negodovanja i protesta civilnog stanovništva. „Na delu puta kroz naseljena mesta, kolona je više puta kamenovana, a vojnici i starešine najgrublje vređani od meštana“. Jedinicama JNA je bilo zabranjeno korišćenje oružja. U selu Vrhpolje probijena je barikada formirana od motornih vozila. Ova kolona odvodi dvojicu meštana Vrhpolja (kasnije pušteni) i uspeva da oko 21 čas stigne u kasarnu „Janko Premrl Vojko“ u Vipavi. „Po pristizanju u kasarnu u Vipavi izvršena je popuna gorivom i kumulativnom municijom i otklonjeni svi propusti oko hrane, vode, lične opreme. Tehnika je pregledana, a ljudstvo odmoreno.“31

\section{Prodor jedinica JNA ka graničnim prelazima, 27. jun 1991.}

Iz slovenačkog republičkog rukovodstva stigle su u međuvremenu informacije da JNA ima nameru da zauzme granične prelaze u noći 26/27. juna. Stoga je rukovodstvo Koordinacijske podgrupe 26. juna uveče odlučilo da se intenzivira obaveštajno-izviđačka delatnost ka graničnim prelazima, u okolini

družbene vede, Ljubljana, 2005); K. Kolšek, $n$. d., 165-168; Rok Filipčič, „Južnoprimorska pokrajina TO“, v: Vojaška obramba Slovenije 1990-1991, 293-296.

${ }_{28}$ SSNO, Uprava Oklopno-mehanizovanih jedinica (UOMJ), Taktička iskustva oklopnih i mehanizovanih jedinica iz upotrebe OMJ u Sloveniji od 26. 06. do 10. 07. 1991, Beograd 1991, 2-3.

${ }^{29}$ SSNO, UOMJ, Taktička iskustva, 6.

${ }^{30} \mathrm{~K}$. Kolšek, $n$. d., 173.

${ }^{31}$ SSNO, UOMJ, Taktička iskustva, 6 . 
kasarni i karaula, da se pojedine jedinice TO maksimalno približe graničnim prelazima i pripreme za borbeno delovanje i da se na svaki način omogući nesmetan saobraćaj preko državne granice. U ove aktivnosti je spadalo i postavljanje velikih barikada na putevima, mahom od teretnih vozila.

Sledećeg dana, 27. juna 1991, u 10.30 časova iz kasarne u Vipavi upućen je vod od tri tenka ka Ajdovščini (severozapadno), ,s ciljem da se lažno prikaže pravac marša“. Jedan tenk otišao je ka Podnanosu (južno). U Ajdovščini, na mostu preko rečice Hubelj postavljena je tog jutra gotovo neprobojna blokada od više naguranih redova kamiona. Pošto je uočeno da nije moguć proboj, tenkovski vod se posle 30 minuta zadržavanja vraća u kasarnu i priključuje borbenoj grupi. ${ }^{32}$

Potom u 11 časova iz kasarne kreće kolona prema granici, sa zadatkom da zaposedne granične prelaze. Oklopnu kolonu čini 14 tenkova T-55, jedan lansirni most MT-55, utovarivač-bager, 25 (23) kamiona sa vojnicima i 4 terenska vozila. ${ }^{33}$ Kolona kreće prema Ajdovščini, ali odmah menja pravac i upućuje se ka selu Slap, na seosku komunikaciju paralelnu sa magistralnim putem ka Novoj Gorici. Pri tome je imala informacije o barikadama na glavnom putu na mostu preko Hubelja i kod Črinče. Velika kolona se kreće kroz sela sa južne strane puta ka Novoj Gorici, ali i na ovom pravcu nailazi na barikade i na neprijateljske reakcije lokalnog stanovništva, koje skoro sve vreme prati kolonu, kako se vidi na fotografijama objavljenim u javnosti. Po podacima JNA - u Dornberku, a po slovenačkim u selu Zalošče, na izlazu iz sela kolona se zaustavlja zbog veće barikade na putu. Posle žestokog napada meštana kamenjem, predmetima i zapaljivim napravama, od kojih je povređen komandir čete a jedan vojnik udaren kamenom, otvorena je vatra na grupu civila koja je protestovala protiv JNA; pri tome je došlo do ranjavanja civila: jednog, prema izveštaju JNA, a više prema slovenačkim izvorima. ${ }^{34}$

Barikada u Dornberku bila je poslednja mogućnost zaustavljanja oklopne kolone, jer je dalje relativno ravan i otvoren put ka granici. U Volčjoj Dragi $(17.20 \mathrm{~h})$ kolona se deli u dve grupe. Jedna ide ka međunarodnom graničnom prelazu u Rožnoj Dolini, a druga ka prelazu Vrtojba. Oba su na periferiji Nove Gorice: jedan severno, a drugi južno. Uz put ka Vrtojbi, mesno stanovništvo na barikadi zasipa kolonu kamenjem, ali otvaranjem vatre (pri čemu su, moguće je, ranjeni neki civili) kolona prolazi i ovu prepreku. ${ }^{35}$ Vod od dva tenka T-55 i jednog kamiona odvaja se iz kolone ka Rožnoj Dolini i odlazi ka Ajševici, radi ojačanja komande graničnog bataljona.

$\mathrm{U}$ isto vreme kada se kolona probija, posle 14.30 časova u rejon Nove Gorice sleću četiri transportna helikoptera Mi-8. Oni iskrcavaju milicionere Saveznog SUP-a (prema podacima JNA njih 43, a prema slovenačkim

\footnotetext{
${ }^{32}$ Isto.

${ }^{33}$ V. Predojević, $n$. d., 95-96; K. Kolšek, $n$. d., 165-168; „Koordinacijska podskupina 'Kronologija'“, v: Njim vsem pripada slava, 817.

${ }^{34}$ SSNO, UOMJ, Taktička iskustva, 6-7.

35 „Kronologija dogajanja in dogodkov“, v: Njim vsem pripada slava, 40; Angel Vidmar, „Spomini na moj kolektiv miličnikov-soborcev in na dogodke v Vipavski dolini“, v: Njim vsem pripada slava, 76.
} 
podacima 90 milicionera $^{36}$ ) koji su imali zadatak da preuzmu kontrolu nad graničnim prelazima. ${ }^{37}$ Ovi milicioneri nisu bili iskrcani na same granične prelaze već su u Ajševici morali da sačekaju dolazak oklopnih kolona. Za to vreme, jedinice TO su blokirale kasarne u Vipavi i Ajdovščini i zaustavile sve eventualne pokrete jedinica JNA u pokrajini. U 15 časova komanda 6. PŠTO izdaje naređenje područnim štabovima da radi izvršenja zadataka koriste celokupno raspoloživo naoružanje. ${ }^{38}$

Snage borbene grupe JNA su tek u toku večeri $(18.40 / 18.50 \mathrm{~h})$ stigle i zauzele granične prelaze Rožna Dolina $(19.40$ h, slovenačka milicija odlazi u 22 h) i Vrtojba $\left(20.57 \mathrm{~h}\right.$, milicija odlazi u $\left.22.30 \mathrm{~h}^{39}\right)$. U trenutku dolaska jedinice JNA na Vrtojbu, na prelazu je bilo 27 milicionera RSUP-a Slovenije. Bila je tu i grupa pripadnika TO, pa su se i oni prema naredbi Koordinacijske podgrupe povukli i prešli u zasedu 700 metara od prelaza. ${ }^{40}$

U Koordinacijskoj podgrupi se tokom noći 27/28. juna raspravljalo o tome kako povratiti granični prelaz. Posle dolaska tenkova na prelaz, mogućnost da se ostala vojska iz karaula preda bila je znatno manja. Nakon duže rasprave, Koordinacijska grupa je na predlog majora Srečka Lisjaka donela odluku da se granični prelaz zauzme iznenada i upotrebom oružja, i pored toga što bi očekivan napad mogao izazvati civilne žrtve i veliku materijalnu štetu. Zauzimanje graničnih prelaza bilo je potrebno i zbog situacije na Severnoj Primorskoj, koja je za slovenačku stranu bila veoma teška jer je JNA uspostavila kontrolu nad svim graničnim prelazima u pokrajini. Zauzimanje prelaza Rožna Dolina imalo bi posebnu važnost $\mathrm{i}$ otklonilo bi pritisak republičkog rukovodstva na komandu 6. PŠTO da nešto preduzme u toj situaciji. Svedočanstvo o tome ostavio je u svojoj knjizi i tadašnji ministar odbrane Janez Janša. On je delovanje svojih snaga na Primorskoj ocenio slabim, poredeći ih sa ostalim pokrajinama. ${ }^{41}$

\section{8. jun - Črniče: prvi sukob i žrtve JNA na Primorskoj}

Sledećeg dana, 28. juna, izbili su oružani sukobi TO Slovenije i snaga JNA u ovoj oblasti. Shodno naređenju 61. područnog štaba TO, na putu Ajdovščina - Nova Gorica, na zapadnoj strani sela Črniče, u pravcu prema Novoj Gorici, Protivdiverzantski vod TO iz Ajdovščine postavio je zasedu i kontrolni punkt za sva vojna vozila. Namera je bila da se na taj način spreči bilo kakva

\footnotetext{
${ }^{36}$ SSNO, UOMJ, Taktička iskustva, 7.

${ }^{37}$ Mitja Močnik, „Bojne aktivnosti bojne skupine 6. Pokrajinskega štaba Teritorialne obrambe Slovenije leta 1991“, Vojnozgodovinski zbornik, št. 29, (2007), 96; Marijan Ipavec, „Dogodki na postaji mejne milice Nova Gorica od 19. 6. do 29. 6. 1991“, v: Njim vsem pripada slava, 766.

${ }^{38}$ VMSV, ZA, OV 1991, t. e. 12; Isto, Z804-02/8, 26. 6. 1991.

39 Jakob Č eferin, „Dogajanje na državni meji v času osamosvajanja 1990-1991 na območju UNZ Nova Gorica“, v: Njim vsem pripada slava, 761.

${ }^{40}$ Vladimir Leban, „Mednarodni mejni prehod Vrtojba 1989-1992“, v: Njim vsem pripada slava, 779; SSNO, UOMJ, Taktička iskustva, 7-8.

41 J. Janša, op. cit., 167, 320; Srečko Lisjak, „Pred 16. leti so uspešno združili sile“, Sobotna priloga, 21. 7. 2007, poštni predal 29, 39 .
} 
komunikacija jedinica na graničnim prelazima i u kasarni Ajševica sa onima $u$ Vipavi. Naređeno je da vod mora da zarobljava pripadnike JNA i da u slučaju njihovog opiranja upotrebi vatreno oružje. ${ }^{42}$

Oko 14 časova, iz pravca Nove Gorice naišla su dva (tri - ?) vojna kamiona TAM-150, iz jedinica koje su bile na graničnim prelazima. Komandir voda TO je pokušao da zaustavi vozila mahanjem ruke, ali ona nisu usporavala. Pripadnici TO i zvanične analize 6. PŠTO kasnije navode da su pripadnici JNA prvi otvorili vatru iz kamiona, pošto je komandir voda pokušao da mahanjem ruke zaustavi vozila. ${ }^{43}$ Prema izjavama meštana, pripadnici TO su prvi otvorili vatru na oba kamiona. Na to su iz kamiona uzvratili vatrom na teritorijalce. ${ }^{44}$ Razvila se opšta pucnjava na vozila. Potom, kada je sve stalo, pripadnici TO su prišli zaustavljenim vozilima i zarobili svu četvoricu starešina u kabinama oba kamiona. U tovarnom delu prvog kamiona nije bilo nikoga, ali kada su teritorijalci podigli cirade drugog kamiona u njemu su otkrili vojnike. Među njima dva mrtva i čak osam ranjenih vojnika. Nastradali vojnici Stipo Ćati i Popaj Halmi bili su iz sastava 228. mtbr (VP 3672). ${ }^{45}$

\section{Veče 28. juna - napad na snage JNA na prelazu Rožna Dolina}

Pošto je u toku prepodneva 28. juna definitivno odlučeno da se prelaz Rožna Dolina zauzme oružjem, narednih sati usledile su pripreme. Izveštaj JNA navodi da su jedinice na prelazima „bile izložene neprestanim provokacijama meštana, naročito u Rožnoj Dolini gde su jedinice bile u naseljenom mestu. Okupila se veća masa meštana oko tenkova. Pokušaji da se pešadijom postavljenom oko tenkova u kordon zaustavi masa ljudi, nisu uspeli, pa čak ni pucanje u vis iz streljačkog naoružanja“. ${ }^{46}$ Kada se pregledaju objavljene fotografije snimljene prepodne 28. juna na ovom graničnom prelazu uočava se da su tenkovi parkirani ispred samog graničnog prelaza u širem rasporedu, da saobraćaj funkcioniše oko njih, da je priličan broj meštana oko tenkova u međusobnom razgovoru ili sa vojnicima, da vojska i savezni milicioneri stoje oko objekta graničnog prelaza, a da je tek po koji vojnik oko tenka ili drugih vozila. Sve u svemu, iako su snage JNA bile brojne i naoružane, ne uočava se njihova ofanzivna delatnost.

Kako se računalo na efekat iznenađenja, za zauzimanje prelaza su određene dve manje grupe snaga TO, jer bi veće grupe sigurno bile primećene. $\mathrm{Za}$ neposredan napad na jedinice JNA određeni su SBS 6. PŠTO koju je vodio major Lisjak i odeljenje posebnih jedinica milicije pod komandom Franca

\footnotetext{
${ }^{42}$ Mitja Premrl, „Črniče, 28. 6. 1991“, v: Njim vsem pripada slava, 843.

${ }^{43}$ VMSV, ZA, OV 1991, t. e. 3, Analiza bojnega dejstvovanja TO 6. PŠTO, 804-03/213, 17. 7. 1991, 3.

${ }^{44}$ VMSV, ZA, OV 1991, t. e. 12, Zapisnik, št. 130-104/2009, 130-132/2009, 130-103/2009, 130-102/2009, 130-101/2009, 130-135/2009, 130-100/2009, 4. avgust 2009, 2.

${ }^{45}$ Narodna armija, jul 1991; M. Premrl, op. cit., 843-844; B. Beltram, op. cit., 544-545; J. Švajncer, op. cit., 130; Vojko Gatnik, „Bolnišnica Nova Gorica, p. o. Šempeter pri Gorici, št.: 4361/91, 6. Avgust 1991“, v: Njim vsem pripada slava, 344-354.

${ }^{46}$ SSNO, UOMJ, Taktička iskustva, 8.
} 
Šumandla. Pripreme za napad su izvršene u strogoj tajnosti, tako da ni komandni sastavi susednih jedinica TO u širem okruženju graničnog prelaza nisu znali za njegovu pripremu i izvršenje. U 17 časova pripadnici SBS TO su se rasporedili između kuća u ulici 25. maja, a milicija u zoni Rožna Dolina - Pristava. ${ }^{47}$

Prema podacima JNA, „oko 17 časova iz putničkog vozila u pokretu su bačene dve zapaljive flaše na tenkove. Obe su promašile tenkove“. ${ }^{48} \mathrm{Na}$ videosnimcima koje su načinili snimatelj Slavko Šuligoj i njegov kolega uočava se da pripadnici unutrašnjih poslova nisu uspeli da u potpunosti uklone civilno stanovništvo sa graničnog prelaza. Pripadnici jedinice SBS TO koja je izvela napad navode da je pred sam početak napada ljudstvo JNA na prelazu pozvano na predaju. Na video-snimcima taj poziv se ne čuje, a slično svedoče i civili-očevici. Iako pripadnici SBS TO tvrde da je poziv upućen, njega najverovatnije uopšte nije bilo. ${ }^{49}$

U 19.20 časova (19.23) pripadnici SBS TO (ukupno njih devetorica) otvaraju vatru na pripadnike JNA. Otvorena je streljačka vatra, a ispaljen je i jedan protivoklopni projektil tipa Armbrust na tenk koji se nalazio na raskrsnici. Podaci JNA navode da su tenkovi ,,pogođeni u motorno transmisiono odeljenje i tom prilikom 4 člana posade su zadobili teže opekotine, a na drugom tenku komandir tenka ostao je bez levog kažiprsta (nalazio se na tenku u momentu kada je tenk bio pogođen).“ On je ,videvši da je susedni tenk zapaljen, a u njemu članovi posade, izašao iz svog tenka da im pomogne“. ${ }^{50}$ Tenk koji se nalazio uz objekat Primexa je posle početka napada upalio motor, počeo okretati kupolu i dejstvovati (19.24). Posle nekoliko minuta paljbe (19.25-19.30), civil Drago Kosmač, koji je pred početak napada pomagao pripadnicima unutrašnjih poslova u naporima da se civili uklone sa graničnog prelaza, upao je u objekat pogranične milicije i tamo razoružao grupu starešina JNA i milicionera SSUP-a. ${ }^{51}$ Pri tom su ga spasila poznanstva sa nekim vojnim licima iz komandnog sastava, koji su se povinovali njegovim naredbama. Kada je razoružao starešine JNA i savezne milicionere, Kosmač je prisilio zastavnika Dragana Tomaševića da improvizovanom belom zastavom objavi predaju snaga JNA (19.30). Oni su zajedno došli do tenka ispred Primexa, kome se još okretala kupola i povremeno oglašavao mitraljez. Tomašević je sve vreme mahao belom zastavom (19,31). Kosmač je u početku pratio Tomaševića sa uperenom automatskom puškom da ovaj ne napravi neki nepromišljen potez. Ali su se potom obojica latili rešavanja

47 „Koordinacijska podskupina 'Zavzetje Rožne doline'“, v: Njim vsem pripada slava, 866-868.

${ }^{48}$ SSNO, UOMJ, Taktička iskustva, 8.

${ }^{49}$ Po izjavama nekih pripadnika SBS, prethodni poziv je upućen. Videti u: Mitja Močnik, „Samostojna bojna skupina TO Nova Gorica“, v: Njim vsem pripada slava, 861; VMSV, ZA, OV 1991, t. e. 12, Boris Lozar, Pisana izjava, 20. 2. 1991. Međutim na video-snimcima Slavka Šuligoja poziv se ne čuje, takođe ni rad Koordinacijske podskupine („,Koordinacijska podskupina 'Zavzetje Rožne doline'“, v: Njim vsem pripada slava, 865-871) ne spominje poziv na predaju. Poziv nisu čuli ni Drago Kosmač (VMSV, ZA, OV 1991, t. e. 12, Drago Kosmač, Pisana izjava, 7. 7. 2009), koji je bio neposredno na graničnom prelazu, kao ni drugi civili i vojnici JNA.

${ }^{50}$ SSNO, UOMJ, Taktička iskustva, $8,18$.

${ }^{51}$ VMSV, ZA, OV 1991, t. e. 3, Analiza bojnega dejstvovanja TO 6. PŠTO, 804-03/213, 17. 7. 1991, 2-3; ,Koordinacijska podskupina 'Zavzetje Rožne doline'“, v: Njim vsem pripada slava, 869. 
zapletene situacije. Kako posada zatvorena u tenku nije čula, a kasnije se ustanovilo ni poznavala Tomaševića, nastavila je sa okretanjem kupole i povremenim dejstvima iz mitraljeza (19.32). To je trajalo sve dok se iz pravca Primexa nije pojavio starešina koji je rukama pokazao da se tenk mora predati. Na tenku je prestala paljba i ugašen je motor (19.33). Potom su vojnici počeli u masi da se predaju (19.35). Uočava se njihova smetenost i nagli pad morala. Među njih se mešaju i civili, a neki od njih pomažu teškim ranjenicima, od kojih najmanje dvojica leže kod utovarivača. Kosmač odvodi veću grupu vojnika sa raskrsnice (19.36), a potom im naređuje da poležu na zemlju. ${ }^{52}$

Potom u 19.36 snage SBS TO ponovo otvaraju streljačku vatru prema mestu gde je nekoliko minuta ranije izvršen napad. Komandir grupe Lisjak opravdavao je ovu pucnjavu negodovanjem nekih oficira JNA koji su se nalazili iza obližnjeg restorana. Oko ovog slučaja je kasnije bilo rasprava u slovenačkoj javnosti. Civili su smatrali da su pripadnici SBS TO morali uočiti da je napad završen i da je na licu mesta bilo dosta onih koji su se uključili na razne načine $\mathrm{u}$ te događaje. Nasuprot tome, pripadnici TO ističu da se još uvek nije znalo kako će se razvijati događaji, ukazujući na zavidnu jačinu snaga JNA na prelazu. Potom u 19.40 na mesto napada dolaze prva vozila hitne pomoći. Preostali pripadnici TO su takođe stigli na mesto događaja. ${ }^{53}$

$\mathrm{Na}$ video-snimcima uočavaju se lakše i teže ranjeni vojnici, a za jednog se govori da je mrtav (19.42). Vide se bolničar i dva civila koji nose jednog vojnika, teško povređenog ili bez znakova života. Uočava se da ranjeni vojnici nisu tenkovske posade već pešadinci. Potom dolazi do eksplozije jednog pogođenog tenka, od koje se upalio i tenk pored njega. Tada nastaju snimci gorećih tenkova na Rožnoj Dolini. Ova dva tenka ostala su i narednih dana na prelazu i bili su dobra prilika za fotografisanje. ${ }^{54}$ Oko 19.44 iz pravca restorana se pojavljuje veća grupa milicionera SSUP-a i njih sprovode ka Šempetru (19.45). Uočava se da su se naoružani civili uključili u sprovođenje vojnika.

U ovom napadu ubijena su tri vojnika: Muhamed Palić, Goran Stanković i Obrad Stevanović, svi iz sastava 63. graničnog bataljona (VP 2146 Nova Gorica). ${ }^{55}$ Po slovenačkim podacima ranjeno je 16 pripadnika JNA, među kojima i komandant bataljona kapetan Kovačič, a po podacima JNA njih 22 je ranjeno. U bolnicu su dovezeni jedan mrtav vojnik i dvadeset ranjenih, od kojih su dvojica preminula: jedan po reanimaciji, a drugi posle operacije. Kod snaga TO i milicije nije bilo povređenih. Ranjeno je šest civila (dva potom puštena kući) zbog neblagovremenog izvlačenja iz zone borbenog dejstva. ${ }^{56} \mathrm{U}$ napadu su uništena dva tenka T-55. Zarobljeno je 98 vojnika. ${ }^{57}$

\footnotetext{
${ }^{52}$ Video: Spopad za mejni prehod Rožna dolina, Vojna za Slovenijo I, dokumentarni posnetki: Slavko Šuligoj, TV tednik, št. 1212/2008.

${ }^{53}$ VMSV, ZA, OV 1991, Mitja Močnik, Pisana izjava, 20. 2. 2010, 1-2; Boris Lozar, Pisana izjava, 20. 2. 2010, 1; „Koordinacijska podskupina 'Kronologija'“, v: Njim vsem pripada slava, 872-874.

${ }^{54}$ Eric Micheletti, Balkans at War, Yugoslavia Divided 1991 (Hong Kong: Concord Publications Company, 1992).

${ }_{55}^{55}$ Narodna armija, jul 1991.

${ }^{56}$ Dokument: „Bolnišnica Nova Gorica p. o Šempeter pri Gorici, Štev. 436 1/91, datum 6/8
} 
Ubrzo, iz republičke koordinacijske grupe stiže naređenje da se sva dejstva prema JNA obustave počev od 21 čas, da se zadrže blokade i ne dozvole nikakvi pokreti jedinica JNA. Takva odluka je bila posledica razgovora predsednika Slovenije Milana Kučana i zamenika sekretara SSNO admirala Staneta Broveta ${ }^{58}$ Pad graničnog prelaza Rožna Dolina i predaja jedinica JNA na njemu sa žrtvama i uništenim tenkovima delovali su kao prekretnica na ovom delu ratišta. I ne samo na njemu već i generalno - na utisak o mogućnostima i moralu snaga TO Slovenije i JNA.

\section{9. jun: predaja snaga JNA na prelazu Vrtojba}

Slom jedinice JNA na prelazu Rožna Dolina bio je presudan za sudbinu jedinice JNA na prelazu Vrtojba. Još iste večeri, Koordinacijska podgrupa je odlučila da treba osloboditi i granični prelaz Vrtojba. U toku noći pojedini građani su zvali podgrupu, prenoseći da se neki od pripadnika JNA nameravaju predati. ${ }^{59}$ Ove najave su se pretvorile u postepenu komunikaciju između snaga JNA na prelazu i raznih predstavnika slovenačke strane tokom prepodneva 29 . juna. ${ }^{60}$ Istovremeno, u široj zoni oko prelaza počinju da se grupišu snage TO Slovenije. Čistina oko prelaza je onemogućavala da se protivnička jedinica neopaženo približi posadi prelaza, čime je i napad bio isključen.

Slovenački izvori konstatuju da su posle 13 časova pomereni tenkovi na prelazu. Potom je jedan meštanin doneo poruku u odeljenje milicije sa predlogom da vojska obustavi sva borbena dejstva i da joj se omogući povratak u kasarne u Ajdovščini i Vipavi. Načelnik uprave unutrašnjih poslova u Novoj Gorici je, preko tog meštanina i milicionera S. Pogelšeka, posle dve runde pregovora u karauli Šempeter postavio zahtev da se vojska bezuslovno preda i ostavi oružje u karauli. Takođe, ponudio je da dva oficira odu do Rožne Doline da bi se uverila u posledice jučerašnjeg napada snaga TO na tamošnju jedinicu. Jedan od njih bio je komandant oklopnog bataljona 228. mtbr kapetan I klase Mile Strajnić. Njemu je preko radio-telefona, verovatno iz komande brigade, ,naređeno oko 14.30 časova da ni sa kim ne pregovara o bilo čemu a posebno (ne) o predaji, da se kružno brani i ne dozvoljava pristup bilo kome bliže od 300 metara" ${ }^{61}$ Nakon sagledavanja posledica ovog napada, pregovori o predaji su bili ubrzani. ${ }^{62}$ Posle 16 sati

1991“, v: Njim vsem pripada slava, 346; „Koordinacijska podskupina 'Zavzetje Rožne doline'“, v: Njim vsem pripada slava, 869-871; SSNO, UOMJ, Taktička iskustva, 8.

${ }^{57}$ Zvonimir Kehler, „Analiza delovanja 6. čete PEM UNZ Nova Gorica v času od 24. 6. 1991 na dalje“, v: Njim vsem pripada slava, 749; Mitja Močnik, „Samostojna bojna skupina TO Nova Gorica“, 862; VMSV, ZA, OV 1991, t. e. 3, Analiza bojnega dejstvovanja TO 6. PŠTO, 80403/213, 17. 7. 1991, 2, 3 .

${ }^{58}$ K. Kolšek, n. d., 203; B. Beltram, op. cit., 545.

59 „Kronologija dogajanja in dogodkov“, v: Njim vsem pripada slava, 44.

${ }^{60}$ Svitoslav Pogelšek, „Vdaja enot na MMP Vrtojba, 29. 06. 1991“, v: Njim vsem pripada slava, 876-882.

${ }^{61}$ SSNO, UOMJ, Taktička iskustva, 8.

${ }^{62}$ S. Pogelšek, op. cit., 876-882. 
dogovorena je predaja jedinice iz karaule i protivoklopne jedinice iz Vipave. Predstavnici slovenačke strane su prihvatili zahtev starešina JNA da se predaja obavi na putu prema Podmarku, da u blizini ne bude niko od lica sa strane, da se vojnici ne smeju fotografisati niti snimati i da se vojnicima potom omogući siguran ulazak u autobuse. Kako je stigla vest o predaji ovog dela snaga JNA, tako su prema Vrtojbi krenuli delovi snaga TO i milicije.

Predaja ove granične i pešadijske jedinice uticaće na brzu predaju jedinice koja je sa tenkovima bila na graničnom prelazu Vrtojba. ${ }^{63}$ Pored vojnika predali su se i milicioneri Saveznog SUP-a. Sve se završilo do 18.15 časova. Vojnici i milicioneri su autobusima odvezeni u Novu Goricu u prostorije Uprave unutrašnjih poslova. Ukupno je zarobljeno 138 pripadnika JNA i zaplenjeno sedam tenkova, šest motornih vozila, jedinica sa 15 raketa Maljutka.

Izveštaj JNA (pisan avgusta 1991), kritički je nastrojen prema komandantu kapetanu I klase Miletu Strajniću i njegovom zameniku kapetanu I klase Voji Mitevu, koje ističe kao „izuzetno negativne primere“: „I pored jakih snaga koje je imao pod komandom, povoljnih uslova za odbranu iako ga niko nije napao, na jedinicu nije ispaljen ni jedan metak, komandant bataljona je predao jedinicu. Ništa nije preduzeo da se tenkovi onesposobe za dalju upotrebu. Jedan primer krajnje neodgovornosti starešine... zamenik k-ta okb je tog momenta pobegao sa položaja“. Pobegao je, kako se navodi, da bi izbegao zarobljavanje: „Imao je priliku da preuzme komandu i spasi jedinicu sramote". ${ }^{64}$ Prema navodima pripadnika Posebnih jedinica milicije Darija Simčiča, odlučan otpor predaji ispoljio je jedan potporučnik-tenkista, ali je posle razgovora sa majorom JNA, koji se već predao i stajao sa strane, odlučio da preda svoje prilično uplašene vojnike. ${ }^{65}$

$\mathrm{Na}$ oba granična prelaza, snage slovenačke TO su zaplenile ukupno deset tenkova T-55 (kao i jedan nosač lansirnog mosta MT-55 i utovarivač ULT). Sutradan je od ovih tenkova oformljena tenkovska četa. Tako je slovenačka TO dobila svoju prvu oklopnu jedinicu. ${ }^{66}$

\section{1. jul: JNA diže skladište Črni vrh u vazduh i napad TO na karaulu Nova Vas}

Posle ovih događaja stanje na međunarodnim graničnim prelazima se smirilo, tako da u naredna dva dana sukoba beležimo samo izdvojene borbene aktivnosti. Jedna od njih je dizanje u vazduh velikog skladišta koje se nalazilo na prelazu iz Vipavske doline ka Idriji, u mestu Črni vrh ob Idrijo. Skladište su ranije obezbeđivale jedinice iz Vipave i Ajdovščine (253. mtbr), a posle organizacijskih promena 1991. jedinice 228. mtbr iz Vipave, sada sa komandom u Postojni.

63 „Koordinacijska podskupina 'Vdaja enot na MMP Vrtojba - 29. 06. 1991'“, v: Njim vsem pripada slava, $883-885$.

${ }^{64}$ SSNO, UOMJ, Taktička iskustva, 8,18 .

${ }^{65}$ Darij Simčič, „Predaja vojaka u Podmarku“, v: Njim vsem pripada slava, 875-876.

${ }^{66}$ VMSV, ZA, OV 1991, t. e. 3, Analiza bojnega dejstvovanja TO 6. PŠTO, 804-03/213, 17. 7. 1991, 4; Toni Gleščič, „Ustanovljena je bila tankovska četa „TONI-55“““, v: Njim vsem pripada slava, 636-639. 
U širem području oko skladišta posle početka sukoba nije bilo jedinica TO Slovenije, ali su civilni osmatrači iz sela nadzirali aktivnosti vojnika u skladištu. Ujutro, 30. juna do skladišta su došli predstavnici lokalne samouprave i komandiru-vodniku ponudili dve mogućnosti: da napusti skladište i vrati se sa vojskom u kasarnu u Vipavi, uz obećanu sigurnost; ili da se predaju jedinicama TO. Komandir je bio aktivni vodnik Baškim Veliči, 20-godišnji Albanac. Pregovori su ponovljeni popodne bez uspeha. Osmatrači oko skladišta su uočili pojačanu aktivnost vodnika i njegovih vojnika u periodu 19-22 časa. U međuvremenu doneta je odluka da se skladište digne u vazduh i da se vojska povuče do obližnje kasarne. Prva manja eksplozija začula se u 01.20 , oko 02.00 buknuo je požar, a velika eksplozija u skladištu odjeknula je u 02.32 časa. ${ }^{67}$ Skladište je odletelo u vazduh. Ujutro oko 9 časova, petorica vojnika (koji su bili poslednji i koji su izazvali eksploziju) probijala se sa stražarskim psom iz skladišta ka kasarni, ali ih je milicija zarobila u rejonu Cola. ${ }^{68}$

Popodne istog dana, snage TO izvršile su napad na karaulu Nova Vas blizu Opatjeg sela. Ova karaula, kojom je komandovao 22-godišnji aktivni vodnik Rama Salihi, pripadala je 63. graničnom bataljonu u Sežani. Povod za napad su bile (navodne) pretnje komandira karaule da će otvoriti vatru na selo. Posle poziva predstavnika seoskih vlasti, Koordinacijska podgrupa je naredila napad na karaulu.

U akciji zauzimanja karaule učestvovali su sada već iskusna SBS 6. PŠTO, odeljenje posebnih jedinica milicije i jedan vod 125. čete za protivdiverzantska dejstva. Posle prikupljanja u Opatjem selu, ove tri jedinice su blokirale karaulu sa svih strana. Oko 14 časova jedan od milicionera a potom i predsednik mesne zajednice pozvali su vojnike na predaju. Potom su u 14.08 snage SBS otvorile vatru na karaulu. Iz karaule je prema bestrzajnom topu na položaju istrčao njen komandir. Međutim, odmah je bio ubijen vatrom slovenačkih snaga. Sa obe strane je potom otvorena vatra, ali je posle dejstva ručnim bacačem na krov karaule postepeno utihnula. Osim ubijenog komandira Salihi Rame, trojica graničara su ranjena, od kojih su dvojica teže ranjenih prevezena u bolnicu u Novoj Gorici. Ukupno su zarobljena 22 pripadnika karaule, a celokupno naoružanje i ubojna sredstva su zaplenjeni. Slovenačke snage nisu imale gubitke. O napadu na karaulu izveštavao je sa lica mesta i novinar BBC-ija. ${ }^{69}$

\section{2. jul: otpor na Ajševici i predaja pojedinih karaula JNA}

Komanda 63. graničnog bataljona u Ajševici ostala je nezauzeta u toku borbenih dejstava i predstavljala je „boleču točku“ za snage TO Slovenije. Sa koman-

${ }^{67}$ „Poročilo komisije za ugotavljanje okoliščin in vzrokov eksplozije v Črnem vrhu“, v: Njim vsem pripada slava, 256-264; B. Beltram, op. cit.. 548.

${ }^{68}$, ,Kronologija dogajanja in dogodkov“, v: Njim vsem pripada slava, 45; A. Vidmar, op. cit., 70.

${ }^{69}$ VMSV, ZA, OV 1991, t. e. 3, Analiza bojnega dejstvovanja TO 6. PŠTO, 804-03/213, 17. 7. 1991, 4; Igor Volk, „Nova vas, 1. 07. 1991“, v: Njim vsem pripada slava, 896-898; Srečko Lisjak, „Zavzetje obmejne stražnice Nova vas, 1. julija 1991“, Vojaška zgodovina, št. 2 (2001), 61-67; J. Švajncer, op. cit., 131; M. Močnik, „Samostojna bojna skupina TO Nova Gorica“, 863-864. 
dantom Mijatovićem predstavnici slovenačke strane vodili su nekoliko razgovora, ali bez uspeha. ${ }^{70}$ „Enota v Ajševici je bila edina, s katero se ni dalo pogovarjati alo dogovarjati o morebitni predaji“, konstatovala je Koordinacijska podgrupa. ${ }^{71}$

Međutim, kao efekat događaja na Rožnoj Dolini, ali i zbog relativno niske motivisanosti snaga JNA, pogotovo u pojedinim izdvojenim objektima (karaulama), došlo je do predaje jednog broja vojnih objekata. Tako su se 2. jula predale karaule u Solkanu, Pristavi, Štanti i Mirenu, sa ukupno 87 pripadnika JNA. $^{72}$

Istog dana, snage slovenačke TO planiraju napad na kasarnu Ajševica. Prikupljeno je više jedinica TO i Milicije, među njima i tenkovska četa TO. U toku dana traju pregovori između komandanta bataljona i predstavnika opštine Nova Gorica. Ukazano je: ako dođe do napada na kasarnu, biće otvorena minobacačka vatra na odabrane ciljeve u gradu. Oko 15.50 časova stiže vest da je jedna tenkovska kolona krenula iz Pivke da bi deblokirala komandu graničnog bataljona u Ajševici kod Nove Gorice. Zbog pregovora sa slovenačkim snagama/vlastima, kolona je stigla samo do Postojne i oko 17.30 vratila se ka Pivci. Potom, u 17.45 prekidaju se pripreme za napad na kasarnu. ${ }^{73}$ Slovenačka četa TO je sa zadatka napada na Ajševicu preusmerena za eventualni sukob sa ovom dolazećom kolonom. U pokretu slovenačke čete kroz naselje Loke, u blizini te kasarne, 2. jula, jedan tenk je oštećen vatrom tenkova JNA iz Ajševice. ${ }^{74}$

Istog dana u 11.40 i 16.45 časova avijacija RV i PVO izvodi napade na RTV predajnik na Nanosu, kao i na nekoliko drugih predajnika širom Slovenije. ${ }^{75}$ Zbog napada na odašiljače u Sloveniji pola časa nije bilo radio ni TV programa. ${ }^{76}$ Nanos je bio na meti avijacije i ranije: prvi napad na ovaj predajnik izveden je 28 . juna u 16.36 časova. ${ }^{77}$

\section{Povlačenje snaga JNA sa Severne Primorske}

Sukob u Sloveniji završen je 7. jula 1991. kada je uz posredovanje ministarske trojke Evropske zajednice potpisana Brionska deklaracija. Uspostavljeno je primirje između snaga JNA i TO Slovenije, dogovoren dolazak međunarodnih posmatrača, tromesečni moratorijum na primenu deklaracija o samostalnosti dve republike i povlačenje svih snaga JNA iz Slovenije. ${ }^{78}$ Predsedniš-

${ }^{70}$ Rajko Novak, „Moji obiski in pogovori s komando 63. obmejnega bataljona JLA v vojašnici „Stanko Furlan Dušan“ na Ajševici“, v: Njim vsem pripada slava, 328-330. Oba oficira su bila pripadnici OMJ: Mijatović komandant 253. okb u Vipavi, a Gavrić komandant 1. okbr u Vrhnici kasnije general u Vojske Republike Srpske.

${ }^{71}$ „Koordinacijska skupina Vojašnica Ajševica - naša boleča (nevralgična) točka“, v: Njim vsem pripada slava, 915.

${ }^{72}$ B. Torkar, op. cit., 377-419; B. Beltram, op. cit., 549.

73 „Kronologija dogajanja in dogodkov“, v: Njim vsem pripada slava, 46.

${ }^{74}$ SSNO, UOMJ, Taktička iskustva, 9.

${ }^{75}$ Isto, 45-46.

76 „Saopštenje komande RV i PVO (10,30). TO Slovenije napada helikoptere sa hranom“, Borba, 3. 7. 1991, 2; „Lažni mir - pravi rat", Novosti, 3. 7. 1991, 5.

77 „Kronologija dogajanja in dogodkov“, v: Njim vsem pripada slava, 43.

${ }^{78}$ K. Nikolić i V. Petrović, $n$. d., 133-135. 
tvo SFRJ donelo je 18. jula Odluku o premeštanju jedinica JNA, a već sutradan ona je razglašena po jedinicama. Čitav posao iseljenja trebalo je da bude završen u roku od tri meseca, a pripadnici slovenačke nacionalnosti iz aktivnog sastava morali su da donesu odluku da li će ostati u JNA ili napustiti službu. ${ }^{79}$

Totalni zbir gubitaka obe strane na Severnoj Primorskoj napravili su organi TO i unutrašnjih poslova Slovenije. Tokom borbenih dejstava u periodu od 26. juna do 7. jula (u suštini od 28. juna do 2. jula) 1991. JNA je imala 6 poginulih i 27 ranjenih pripadnika, ${ }^{80}$ TO Slovenije jednog ranjenog pripadnika, a bilo je ranjeno ili povređeno još 12 civila. Iz sastava JNA prebeglo je 37 starešina, 345 vojnika i 33 građanska lica. Zarobljena su 533 pripadnika. Materijalni gubici su sledeći: dva tenka T-55 su uništena, a deset T-55 i jedan lansirni most su zaplenjeni. Takođe, zaplenjeno je 20 teretnih motornih vozila, 11 terenskih vozila, jedan utovarivač i oko 950 tona streljačkog i drugog naoružanja, municije i materijalno-tehničkih sredstava. ${ }^{81} \mathrm{Na}$ dan 8 . jula, TO je kontrolisala skladište na Šentviškoj Gori i kasarnu Bovec. Iz 64. graničnog bataljona - Sežana, zauzeta je karaula Nova Vas. Iz 63. graničnog bataljona - Nova Gorica civilima su predate karaule Šanta-Miren, Pristava, Solkan, predate miliciji ili TO Miren, Šempeter i Hum. Iz 62. graničnog bataljona - Tolmin zauzeta je samo karaula Livek. Sve ostale su i dalje bile pod kontrolom JNA. ${ }^{82}$

Usledilo je premeštanje jedinica JNA iz Slovenije. U Primorskoj, armija je napustila sve karaule na ovom prostoru od 20. do 23. jula, odnosno do 25 . jula na području graničnog bataljona u Tolminu, a dinamika preuzimanja vojnih objekata dogovorena je 5. avgusta na sastanku u Ajdovščini. Poslednji pripadnici JNA napustili su 19. oktobra kasarnu „Janko Premrl Vojko“ u Vipavi. Poslednji preostali pripadnici JNA sa ličnom opremom i naoružanjem napustili su Sloveniju trajektom iz luke Koper 26. oktobra $1991 .^{83}$

Jedinice JNA su u borbama u Sloveniji ispoljile razne nedostatke, pa tako i na području Severne Primorske: vojska angažovana na granici nije bila pripremljena za borbu - koju nije ni očekivala, a veliki deo vojnika nije hteo da se bori. Vladala je opšta iznenađenost zbog otpora i ponašanja TO Slovenije, 27-28. juna. ${ }^{84}$ Snage JNA su u suštini imale neadekvatan zadatak - da dejstvujući iz dubine teritorije zauzmu i obezbede granične prelaze republike u kojoj su bazirali, koja je potom proglasila svoju samostalnost i tako postala neprijateljski

${ }^{79}$ Isto, 282-284.

80 „Zlodela na slovenački način“, Vojska, 26. 11. 1992. Podaci iz novogoriške bolnice navode da je pored 6 mrtvih bilo 36 hospitalizovanih i 6 ambulantno obrađenih pripadnika JNA, iz sastava TO: 17 hospitalizovanih i 9 ambulantno obrađenih pripadnika, kao i 9 odnosno 5 ambulantno obrađenih civila. V. Gatnik, op. cit.. 353.

${ }^{81}$ Friderik Markovčič, „Goriška v osamosvojitveni vojni leta 1991“ (diplomski rad, Univerza u Ljubljani, Fakulteta za družbene vede, Ljubljana, 2013), 79.

${ }^{82}$ B. Beltram, op. cit., 551-552; J. Čeferin, op. cit., 763.

83 „Kronologija dogajanja in dogodkov“, v: Njim vsem pripada slava, 49-51; Vito Berginc, „Vojna za samostojno Slovenijo 1991 na območju 63. Obm ŠTO Tolmin“, Vojnozgodovinski zbornik, br. 7, (2001), 122; J. Janša, op. cit., 257-265; „Koraki na veliki poti“, Revija Obramba, 11. novembar 1998, 13.

${ }^{84}$ K. Kolšek, n. d., 207. 
nastrojena. Oklopne i motorizovane pešadijske snage kretale su se kroz teritoriju praćene neprijateljskim odnosom stanovništva i blokadama magistralnih puteva. Po dolasku na granične prelaze dve borbene grupe su ostale odsečene od matičnih garnizona (Pivka, Vipava); one su kao i pojedine izolovane karaule bile lakša meta, u suštini naoružanjem i brojnošću inferiornijim snagama TO Slovenije. Jedinice JNA u kasarnama ili velikim skladištima na Primorskoj ostale su blokirane i nenapadnute od snaga TO, pa su bez većih posledica dočekale primirje.

S druge strane, zajedno sa milicijom i civilnim strukturama i stanovništvom, snage TO Slovenije na Primorskoj su izvršile sve borbene zadatke i po primirju uspostavile potpun nadzor na svojoj zoni odgovornosti. Slovenačka strana posebno ističe rukovođenje i komandovanje/koordiniranje svih borbenih aktivnosti ili pregovora koje je vodila Koordinacijska podgrupa, koja je povezivala sve aktivnosti TO, Milicije i ostalih subjekata. Mnogi nedostaci jedinica TO - od nestašice adekvatnog naoružanja i sredstava veze, do neuhodanosti kao posledice brzog prelaska iz mobilizacije u borbena dejstva - nadomešteni su činjenicom da je na obe strane (sa retkim izuzecima) bilo volje i raspoloženja za pregovore i dogovore. ${ }^{85}$ Uočava se da je dve od tri ofanzivne akcije prema JNA izvela jedinica od devet ljudi pod komandom Srečka Lisjaka. Njeni napadi su u suštini bili presudni za snage JNA koje su zauzele granične prelaze u rejonu Nove Gorice i naneli su im najviše žrtava.

\section{REFERENCE}

- Bačar, Stanislav, ur. Njim vsem pripada slava: osamosvojitveno dogajanje Ajdovščina, Idrija, Nova Gorica, Tolmin. Nova Gorica: Goriški muzej, 2009.

- Berginc, Vito. „Vojna za samostojno Slovenijo 1991 na območju 63. Obm ŠTO Tolmin“. Vojnozgodovinski zbornik, br. 7, (2001).

- Berginc, Vito. „Načrt „Jezero““. V: Trdna mreža: osamosvajanje Slovenije v Zgornjem Posočju. Ur. Roman Medved, 95-96. Tolmin: Območno združenje veteranov vojne za Slovenijo Gornje Posočje, 2008.

- Filipčič, Rok. „Južnoprimorska pokrajina TO“. V: Vojaška obramba Slovenije 1990-1991. Ur. Tomaž Kladnik, 293-296. Ljubljana: Defensor, 2011.

- Janša, Janez. Premiki, nastajanje in obramba slovenske države 1988-1992. Ljubljana: MK, 1992.

- Kladnik, Tomaž, ur. Vojaška obramba Slovenije. Ljubljana: Defensor, 2011.

- Kladnik, Tomaž. „Teritorialna obramba v obrambi suverenosti Republike Slovenije“. V: Vojaška obramba Slovenije 1990-1991. Ur. Tomaž Kladnik, 7-17. Ljubljana: Defensor, 2011.

- Kolšek, Konrad. Prvi pucnji u SFRJ, sećanja na početak oružanih sukoba. Beograd: Dangraf, 2005.

- Križman, Silva. Dan prej. Koper: Primorske Novice, 1994.

\footnotetext{
${ }^{85}$ B. Torkar, n. d., 395.
} 
- Lisjak, Srečko. „Pred 16. leti so uspešno združili sile“. Sobotna priloga, 21. 7. 2007.

- Lisjak, Srečko. „Zavzetje obmejne stražnice Nova vas, 1. julija 1991“. Vojaška zgodovina 2, št. 2, (2001).

- Lovšin, Andrej. Skrita vojna, spopad varnostno-obveščevalnih služb 19901991. Ljubljana: Alpe Avro, Mladinska knjiga, 2001.

- Markovčič, Friderik. „Goriška v osamosvojitveni vojni leta 1991“. Diplomski rad, Univerza u Ljubljani, Fakulteta za družbene vede, Ljubljana, 2013.

- Marijan, Davor. Smrt oklopne brigade. Zagreb-Sarajevo: Naklada Zoro, 2002.

- Medved, Roman, ur. Trdna mreža: osamosvajanje Slovenije v Zgornjem Posočju. Tolmin: Območno združenje veteranov vojne za Slovenijo Gornje Posočje, 2008.

- Micheletti, Eric. Balkans at War, Yugoslavia Divided 1991. Hong Kong: Concord Publications Company, 1992.

- Močnik, Mitja. „Bojne aktivnosti bojne skupine 6. Pokrajinskega štaba Teritorialne obrambe Slovenije leta 1991“. Vojnozgodovinski zbornik, št. 29, (2007), 96-100.

- Nikolić Kosta, i Vladimir Petrović. Rat u Sloveniji. Dokumenta Predsedništva SFRJ 2. Beograd: ISI, 2012.

- Predojević, Vaso. U procjepu, dnevničke zabilješke o razbijanju Partije, Armije, Države. Beograd: Dangraf, 1997.

- Race, Helena. „Dan Prej 26 junij 1991“. Diplomsko delo, Univerza u Ljubljani, Fakulteta za družbene vede, 2005.

- Spopad za mejni prehod Rožna dolina, Vojna za Slovenijo I, dokumentarni posnetki: Slavko Śuligoj, TV tednik, št. 1212/2008.

- Švajncer, Janez J. Obranili Domovino: teritorijalna obramba Republike Slovenije v vojni za svobodno in samostojno Slovenijo 1991. Ljubljana: Viharnik, 1993.

- Torkar, Blaž. „Severnoprimorska pokrajina TO“. V: Vojaška obramba Slovenije 1990-1991. Ur. Tomaž Kladnik, 377-419. Ljubljana: Defensor, 2011. 
BLAŽ TORKAR, PhD, Research Associate

Military School Center of the Slovenian Army/Military Museum

Maribor, Republic of Slovenia

blaž.torkar@gmail.com

BOJAN B. DIMITRIJEVIĆ, PhD, Principal Research Fellow

Institute of Contemporary History

Belgrade, Republic of Serbia

bojands1@gmail.com

\section{THE CLASH BETWEEN THE YUGOSLAV PEOPLE'S ARMY AND SLOVENIAN TERRITORIAL DEFENCE IN NORTHERN PRIMORSKA REGION 1991}

\section{Summary}

The article provides a detailed description of armed conflict in the Primorska region during War in Yugoslavia or Slovenian Independence War, from June 26 to July 7, 1991. The Slovenian TO was commanded by the Republic Slovenia Territorial Defence Headquarters and it was consisted of seven regional Headquarters. One of them was the 6th Regional Staff of Territorial Defence of the Northern Primorska. On the other side, most of the JNA forces in the area of Northern Primorska during 1991 were controlled by the $228^{\text {th }}$ Motorised brigade and two border Battalions in Sežana and Nova Gorica. The movement of the JNA units upon the orders of the Federal Yugoslav Government with the intention to seize the international border crossings with Italy, and halt the process of the Slovenian independence, started from the barracks in Pivka to the Vipava Valley on ,the day before“, the $26^{\text {th }}$ June 1991 . On the following day the JNA units occupied main international border crossings around Nova Gorica. The attack of Slovenian TO units and defeat in Rožna Dolina border crossing on the $28^{\text {th }}$ June was a turning point in the clash in the Primorska. Following this incident another armoured unit at the Vrtojba border crossing surrendered on the following day. That development led to collapse of the eventual JNA further movements and operations. The most important aspect of the conflict in Northern Primorska region during Slovenian Independence War was its negotiated resolution between JNA and Slovenian political and defence structures, mostly without using arms. Some of the guardhouses surrendered to Slovenian forces, and in the afternoon of the $2^{\text {nd }}$ July the ceasefire was arranged. In following days the international arbitration help the process of the negotiations between the Federal Yugoslav and Slovenian authorities, which resulted in decision that JNA forces should withdraw from Slovenia in period between August and October 1991.

KEYWORDS: Yugoslavia, Slovenia, Primorska, Yugoslav People's Army, Territorial Defense, War 